\title{
Original article (short paper) \\ Selective loads periodization attenuates biochemical disturbances and enhances performance in female futsal players during competitive season
}

\author{
Ricelli Endrigo Ruppel da Rocha \\ Instituto Universitário Italiano de Rosario, Argentina \\ Everson Araújo Nunes \\ Universidade Federal de Santa Catarina, Brazil \\ Graciela Delia Venera \\ Instituto Universitário Italiano de Rosario, Argentina
}

\begin{abstract}
This study evaluated the effect of selective loads periodization on physical performance and biochemical parameters in professional female futsal players during competitive season. Twelve elite female futsal players from Kindermann team (Brazil) participated in the study. Variables of physical performance and erythrogram, leukogram, plasma cortisol, plasma immunoglobulin $\mathrm{A}(\operatorname{IgA})$ in the beginning of the preparatory period (PP), in the competitive period (CP) and in the final competitive period (FCP) were evaluated. Using selective loads periodization, all variables of physical performance increased ( $p<.01)$ during CP and were maintained during $\mathrm{FCP}(p<.05)$. White blood cells did not modify during CP and the increase of FCP in $28 \%$ remained within normal ranges. Plasma cortisol also increased during CP $(p<.01)$ and was within the normal ranges during FCP. Plasma IgA also was within the normal ranges during CP and FCP. Selective loads periodization is adequate and attends the requirements of the sport during competitive season in female futsal players.
\end{abstract}

Keywords: athletes, training, planning, hematology, immune system

Resumo - "Periodização com cargas seletivas atenua distúrbios bioquímicos e melhora o desempenho físico de jogadoras de futsal feminino durante temporada competitiva." Este estudo avaliou o efeito da periodização com cargas seletivas sobre o desempenho físico e parâmetros bioquímicos em jogadoras profissionais de futsal feminino durante temporada competitiva. Participaram do estudo 12 atletas da equipe do Kinderman. Foram avaliados variáveis de desempenho físico, eritrograma, leucograma, cortisol plasmático, imunoglobulina A plasmática (IgA) no início do período preparatório (PP), durante o período competitivo (PC) e no período competitivo final (PCF). No PC todas as variáveis de desempenho físico aumentaram $(p<0,01)$ e foram mantidas no PCF $(p<0,05)$ com a periodização do treinamento. Os glóbulos brancos não se modificaram no $\mathrm{PC}$ e o aumento de $23 \%$ no PCF permaneceu dentro dos valores normais. O cortisol plasmático aumentou no PC $(p<0,01)$, mantendo-se dentro dos valores normais no PCF. Imunoglobulina A (IgA) também ficou dentro dos valores normais durante PC e PCF. A periodização com cargas seletivas é adequada e atende as exigências da modalidade durante a temporada competitiva em jogadoras de futsal feminino.

Palavras-chave: atletas, treinamento, planejamento, hematologia, sistema imunológico

Resumen - "Periodización con cargas selectivas atenúa desórdenes bioquímicos y mejora el desempeño físico en jugadoras de futsal femenino durante etapa competitiva." Este studio evaluó el efecto de la periodización con cargas selecivas sobre el desempeño físico y parámetros bioquímicos en jugadoras profisionales de futsal femenino durante etapa competitiva. Participarón de este estudio 12 jugadores de futsal de la equipo de la Kinderman (Brazil). Se evaluaron variables de desempeño físico, eritrograma, leucograma, cortisol plásmatico e inmunoglobulina A (IgA) previo al inicio del period preparatorio (PP), durante period competitivo (PC) y period competitivo final (PCF). En el PC todas las variables del desempeño físico aumentaron $(p<0,01)$ y se mantuvieron en el PCF con la periodización del entrenamiento. Los glóbulos blancos no se modificaron en el PC y el aumento de $23 \%$ en el PCF estaban dentro de los rangos normales. Cortisol plasmático aumentó en el PC $(p<0,01)$ y se mantuvo dentro de los rangos normales en el PCF. Inmunoglobulina A (IgA) también se mantuvo en los rangos normales en el PC y PCF. La periodización con cargas selectivas es adecuada $\mathrm{y}$ atende las exigências del deporte durante toda la etapa competitiva de las jugadoras de futsal femenino.

Palabras claves: atletas, entrenamiento, planificación, hematologia, sistema immune 


\section{Introduction}

In Brazil, futsal is the sport with the highest number of practitioners with almost 12 million followers (Salles \& Moura, 2013). According to FIFA (2006), 175 thousand women are currently officially enrolled in regular competitions worldwide.

During the futsal season, female players are engaged in several competitions. They often play two or more games a week, with short rest periods and inadequate recovery to restore energy reserves, increasing muscle and psychological fatigue. Frequently, athletes show high disease and infection incidence, increased injury risk during pre-season training periods which yields decreased the physical performance of teams during games (Avloniti et al., 2007).

In order to decrease the negative effects during the training process, the group of associated goals intended to be reached in short, medium and long term are pursued by systematizing a set of plans and control for training, also known as periodization. The Block Periodization model proposed by Verchoshansky (1985) has been used for team sports such as soccer (Wahl, Güldner, \& Mester, 2014), basketball (Moreira, Oliveira, Okano, Souza, \& Arruda, 2004) and male futsal (Toledo \& Corradine, 2008), however, no study with female futsal players was carried out until this time with others periodization models during competitive season.

The selective loads periodization model was organized in order to fulfill the calendar of soccer teams, because players have 57 to 85 matches during the season, hampering the distribution of training loads in the macro cycle (Gomes, 2002). This model arises because in soccer there is not enough time to adequately prepare the athletes before the onset of the official games. This model of periodization aims to improve the speed capabilities, with unchanged volume and monthly adjustments of physical capacity during the competitive cycle (Gomes, 2002).

Here we investigate the effect of selective loads periodization model on physical performance in one female futsal team. Furthermore, hematological and immunological parameters during competitive season were evaluated as well. We hypothesize that this periodization model will be able to improve and maintain physical performance during the competitive season as well as decrease physiological and hematological adverse effects in female futsal athletes.

\section{Methods}

\section{Particiapants}

Twelve elite female futsal players (Aged $23 \pm 5$ years; Height $160.0 \pm 5.8 \mathrm{~cm}$ ) from Kindermann team (Brazil) participated in the study. All players took part of the main competitions (National League, State Championship, Brazilian College Games and Open Games of Santa Catarina) during the
2011 Brazilian season. All players were full time professional and trained on a daily basis. The athletes were previously informed of all experimental procedures and provided a written informed consent, which was approved by the Institute's Ethics Committee at the State University of Santa Catarina (149/2011, September 30, 2011).

\section{Periodization of training}

Periodization of training had a structure of an annual macrocycle. It was based on the model of Selective Loads proposed by Gomes (2002), with minor modifications. The periodization as well as physical, tactical and technical training for the competitive season were developed and adopted in accordance with the following criteria: a) Calendar of matches; b) Scientific principles of sports training; c) Four distinct periods (preparatory, competitive, final competitive and transition period); d) Special and specific phase; and e) Basic structural units of sports training (training session, training day, microcycle, mesocycle).

The macrocycle began on the first week of February and finished on the third week of November, making 10 training mesocycles. Mesocycles were composed of 4 weeks, divided in 4 microcycles of 7 days, totaling 40 microcycles and 240 days of training. Table 1 shows the periodization of training:

The macrocycle was divided in four periods and two phases:

Preparatory Period (PP) - began in the first week of February and finished in the first week of April, totaling 9 microcycles and 2 mesocycles of training. The first mesocycle was designed to develop aerobic endurance, localized muscular endurance and flexibility. On the second training mesocycle the emphasis was focused on velocity, agility, upper and lower limbs muscle power, submaximal force and maintenance of physical capacities mentioned above.

Competitive Period (CP) - began in the second week of April with the National League Competition and finished in the last week of October. This period was composed of 7 competitive mesocycles divided in 28 training and competition microcycles. The aims were to decrease training volume and to increase intensity, with emphasis on physical capacities of speed and agility,

Final Competitive Period (FCP) - began on the first week of November and finished on the third week of November with the last competition of the season. This period consisted of 1 mesocycle and 3 microcycles, emphasizing the technical and tactical training. A few physical training sessions aiming to maintain physical capacities developed in the previous mesocycles were performed.

Transition Period (TP) - began on the last week of November, after they finished the last game of the season. In this period, the athletes entered on vacation.

The chart 1 shows the activities in each period and mesocycle training: 
Table 1. Periodization of training from 2011 competitive season.

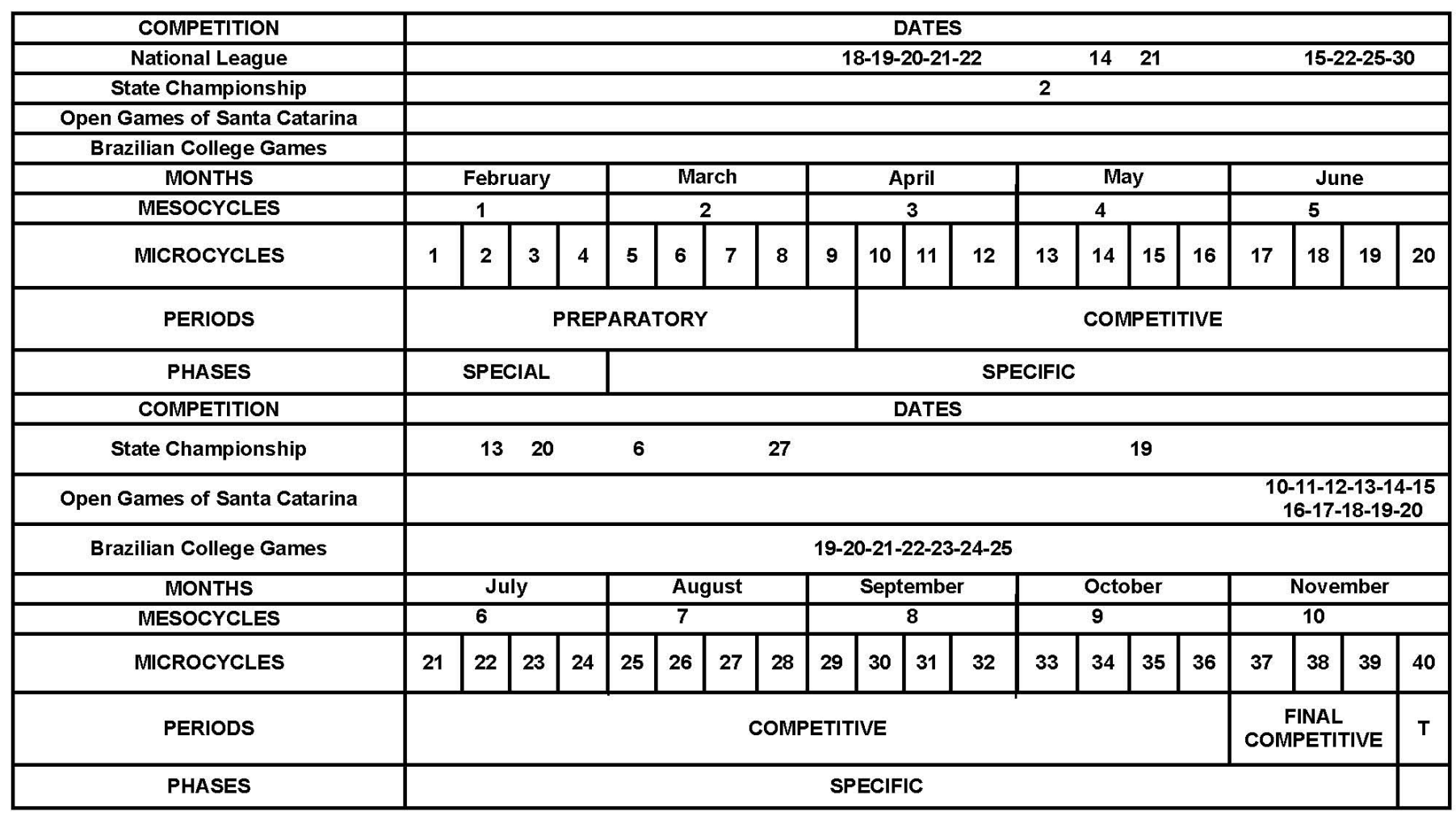

Chart 1. List of activities in each period and mesocycle training

\begin{tabular}{|c|c|c|}
\hline Period & Mesocycle & Activities \\
\hline \multirow[t]{2}{*}{ Preparatory (PP) } & M1 & 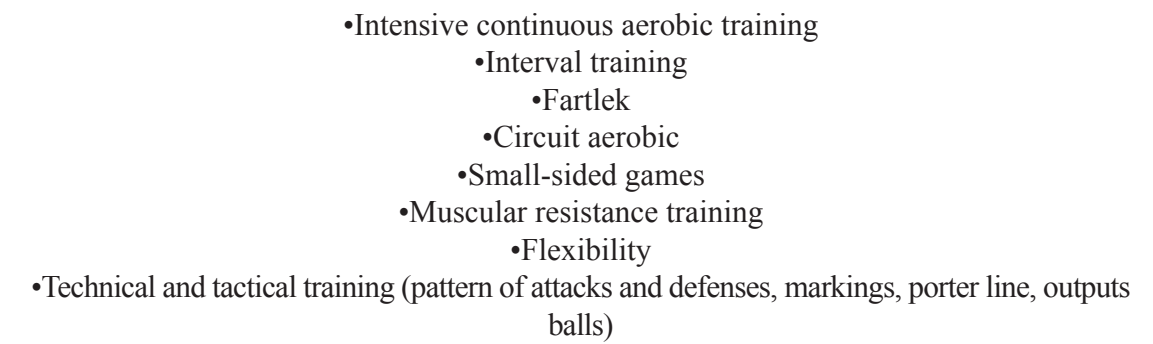 \\
\hline & M2 & $\begin{array}{c}\cdot \text { Plyometric exercises } \\
\cdot \text { Agility and speed circuits } \\
\cdot \text { Reduced game } \\
\cdot \text { Functional exercises } \\
\cdot \text { Strength training } \\
\cdot \text { Technical and tactical training (pattern of attacks and defenses, markings, porter line, } \\
\text { outputs balls, side outputs and rehearsed plays) }\end{array}$ \\
\hline Competitive (CP) & $\begin{array}{l}\text { M3 } \\
\text { M4 } \\
\text { M6 } \\
\text { M7 } \\
\text { M8 } \\
\text { M9 }\end{array}$ & $\begin{array}{c}\cdot \text { Plyometric exercises } \\
\cdot \text { Agility and speed circuits } \\
\cdot \text { Reduced game } \\
\cdot \text { Functional exercises } \\
\cdot \text { Technical and tactical training (correction of positioning errors, rehearsed plays, pattern of } \\
\text { attacks and defenses) }\end{array}$ \\
\hline Final Competitive (FCP) & M10 & $\begin{array}{c}\cdot \text { Few agility and speed circuits } \\
\text {-Technical and tactical training (correction of positioning errors, rehearsed plays, pattern of } \\
\text { attacks and defenses) }\end{array}$ \\
\hline Transition (T) & - & -Vacation \\
\hline
\end{tabular}




\section{Study design}

All assessments of physical performance, biochemical and immunological parameters and body composition were carried out: a) at the beginning of the preparatory period, that comprised the first day the athletes met to begin training; b) in the competitive period (fourth week of April, 48 hours after have competed the initial phase in the National League); and c) in the final competitive period covering seven days before the last final games (first week of November, 48 hours after the last exercise training). The athletes could not present diseases and injuries throughout the assessment period. It was recommended to the athletes to keep their usual diets. The menstrual cycle periods and the use of ergogenic substances were not controlled.

The assessments of hematological parameters, immunoglobulin A ( IgA) and serum cortisol (day 1) were carried out in the clinical analysis laboratory Madalozo Camatti Ltda (Caçador, Brazil). The physical and performance tests were carried out in the multisport court from Alto Vale University of Rio do Peixe, (UNIARP) in the afternoon (14:00 to 18:00 hours), in two days: a) day 2 - explosive power, agility, isometric maximum strength, muscular endurance; b) day 3 - body composition, aerobic capacity $\left(\mathrm{VO}_{2 \max }\right)$ and flexibility.

\section{Body composition}

The body composition assessment was carried out in the morning (09:00 to 11:00 hours) in a reserved room at the sports arena where athletes trained. The following sequence was used to evaluate body composition: height, total body mass and skinfold. To evaluate

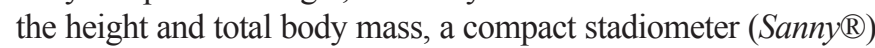
was used with accuracy of $0.1 \mathrm{~cm}$ and a scale (Filizola ${ }^{\circledR}$, Model 31, Brazil) with accuracy of $100 \mathrm{~g}$, according to the procedures described by Gordon, Chumlea, and Roche (1988). To evaluate skinfold a scientific plicometer (Cescorf, Brazil) with accuracy of $0.1 \mathrm{~mm}$ was used, according to the procedures described by Harrison, Buskirk, and Carter (1988). Seven skinfolds (triceps, subscapularis, suprailiac, abdominal, chest, mid-axillary and thigh) were measured. The equation of Siri (1961), as from the body density estimation determined by the equation proposed by Jackson and Pollock (1978) was used to estimate relative body fat ( $\%$ fat).

\section{Assessment of physical performance}

\section{Maximal oxygen uptake}

Maximal oxygen uptake $\left(\mathrm{VO}_{2} \max \right)$ was indirectly obtained using a multistage 20-meters shuttle run test (Leger \& Lambert, 1982). Subjects ran between two lines $20 \mathrm{~m}$ apart following a specific time guided by a sound signal emitted from an audio cassette. The frequency of the sound signals increased every minute. The test was finished when the subject was no longer able to follow the set pace and did not reach the targeted line on three consecutive trials. The level attained and the number of shuttles at that level allowed a prediction of $\mathrm{VO}_{2} \max$, according to Leger and Lambert (1982).

\section{Lower limb muscle power}

Standing long jump test was used to indirectly assess the lower limb muscle power in accordance with the procedures by Matsudo (1987). All players were instructed to perform a long jump from a standing position. Standardized instructions were given to players that permitted them to begin the jump with bent knees and swing their arms to assist in the jump. A line drawn on a hard surface served as the starting line. The length of the jump was determined using a tape measure, which was affixed to the floor. Each player was given 3 trials, and the distance of the best jump was measured, to the nearest $1 \mathrm{~cm}$, from the line to the point where the heel closest to the starting line landed. If the player fell backward, the distance where the body part closest to the starting line touched the ground was measured as the jump's length. Each player performed 3 jumps, whether or not a subject fell backward during an attempt. The longest jump was used as the test score.

\section{Flexibility}

The sit and reach test was used to measure the flexibility of the lower back and hamstring muscles in accordance with the procedures by Wells and Dillon (1952). The athletes sat on the floor with legs out straight ahead. The feet (shoes off) were placed with the soles flat against the box, shoulder-width apart. Both knees were held flat against the floor by the tester. With hands on top of each other and palms facing down, the athletes reached forward along the measuring line as far as possible. After reaching three times, the fourth reach was held for at least two seconds while the distance was recorded. The score (in $\mathrm{cm}$ ) was recorded to the nearest centimeter as the distance before or beyond the toes.

\section{Agility}

Shuttle run test was used to measure the agility in accordance with the procedures by Matsudo (1987). Two lines 9.14 meters apart were marked using marking tape. Two blocks were placed on the line opposite the line they had to start the test. On the signal "ready," the athletes placed their front foot behind the starting line. On the signal "go!" the athletes sprinted to the opposite line, picked up a block of wood, ran back and placed it on or beyond the starting line. Then, turning without a rest, they ran back to retrieve the second block and carry it back across the finish line. Two trials were performed. Only the best score was recorded in seconds.

\section{Upper body strength and endurance}

Push-up and sit-up test were used to measure the upper body strength and endurance in accordance with the procedures by Pollock and Willmore (1993). The athletes started in the push up position - with the hands and toes touching the floor, the knees on the ground, feet slightly apart, and the arms at shoulder width apart, extended and at right angles to the body. The athletes lower 
the body until there is a 90-degree angle at the elbows, with the upper arms parallel to the floor and then back up. The number of correctly completed performed push-ups was recorded. For the sit-up test the athletes laid on a cushioned, flat, clean surface with knees flexed at 90 degrees. The hands were placed by side of the head and the athlete raises the trunk in a smooth motion, keeping the arms in position, curling up the desired amount. The trunk was lowered back to the floor so that the shoulder blades or upper back touch the floor. The number of the correctly completed sit-ups in $1 \mathrm{~min}$ became the score.

\section{Isometric maximum strength}

Leg and back dynamometer (Takey - TKK 5002, Type 2) test was used to measure the maximum isometric strength of the lower limbs and lower back muscles in accordance with the procedures by Johnson and Nelson (1979). With the dynamometer calibrated and set to zero, the athletes were placed at the base of the dynamometer. The drawbar was placed at the level of inguinal fold and they performed a knee extension without bending the body. Two trials were performed with one minute of rest among them. Only the higher score (in kilogram) on the drawbar was recorded.

\section{Biochemical assessment}

\section{Venous blood sampling}

The blood samples of athlete were withdrawn from the antecubital vein in the morning in the fasting state after staying at least $15 \mathrm{~min}$ in a sitting position. A $5 \mathrm{ml}$ sample of blood was collected in a glass Vacutainer tube containing the anticoagulant tripotassium ethylenediaminetetra-acetic acid ( $\mathrm{K}_{3}$-EDTA) and used to determine full blood counts. Immediately after the collection, the blood samples were centrifuged for plasma separation. Plasma was quickly frozen and stored at $-70^{\circ} \mathrm{C}$. Whole blood count and some plasma and clinical parameters were measured in samples according to the laboratory standard operating procedures.

\section{Hematology}

Hemoglobin concentration, hematocrit, red blood count (RBC), percentage of reticulocytes, mean cell volume (MCV), mean corpuscular hemoglobin $(\mathrm{MCH})$, and mean cell hemoglobin concentration (MCHC) were determined by using the automated system Sysmex K-1000 (TOA Medical Electronics Co. Ltd.).

\section{Leukocyte differential counts}

Leukocytes [white blood cells (WBC)] numbers were analyzed in EDTA whole blood using the Sysmex K-1000 (TOA Medical Electronics Co. Ltd.). Coefficients of variation (CV) for neutrophils and lymphocytes counts were $<4 \%$.

\section{Plasma immunoglobulin (IgA)}

Immunoglobulin A was measured in plasma samples by immunoturbidometric assay (Pentra 400 autoanalyser, Horiba, France) according to the recommendations of the manufacturer.

\section{Blood cortisol}

Plasma cortisol concentration was measured with a solid -phase competitive chemiluminescent enzyme immunoassay in a calibrated IMMULITE 2000 analyzer (Diagnostic Products Corporation, Los Angeles, CA, USA)

\section{Statistical analyses}

The results are presented as mean \pm standard deviation (SD). Data distribution was analyzed by the Shapiro-Wilk test. In order to analyze the effects of training periodization at different periods of the competitive season, the one way analysis of variance with repeated measures (ANOVA) was applied. When a significant effect was detected, post hoc analyses were carried out using Tukey test. The value of $p<.05$ indicates statistical significance. All data were analyzed using the Graph Pad Prism software, version 5.0.

\section{Results}

\section{Body composition}

Selective loads periodization did not modify the body weight (Table 2) in the competitive period and final competitive period when compared with beginning of preparatory period $(p>.05)$. Body fat reduced by $15 \%$ in the final competitive period when compared with beginning of preparatory period ( $p$ $<.001)$ and by $10 \%$ in the competitive period when compared with the preparatory period $(p<.05)$ (Table 2$)$. The lean body mass increased by $2 \%$ and $3 \%$ in the competitive period and final competitive period when compared with the beginning of preparatory period $(p<.05)$ (Table 2$)$. Nevertheless, there was a reduction in the fat body mass by $23 \%$ in the final competitive period compared to preparatory period $(p<.05)$ (Table 2$)$.

\section{Physical performance}

Selective loads periodization in the competitive period increased maximal oxygen uptake $\left(\mathrm{VO}_{2} \max \right)$ by $14 \%(p<.01)$. Maximum isometric strength of the lower limbs and lower back muscles was increased by $17 \%(p<.01)$, lower limb muscle power by $12 \%(p<.001)$, flexibility by $8 \%(p<.001)$, and muscle endurance during sit-up and push-up tests by $17 \%$ and $40 \%$ ( $p$ $<.001$ ), respectively (Table 3). Furthermore, the periodization increased the agility of the athletes reducing the time by $7 \%$ when compare with beginning of preparatory period $(p<.05)$ (Table 3$)$. 
Table 2. Effect of selective loads periodization on body composition of female futsal players in the beginning of the preparatory (PP), competitive (CP) and final competitive period (FCP).

\begin{tabular}{lccc}
\hline & PP & CP & FCP \\
\hline Body weight (kg) & $59.8 \pm 3.6$ & $59.0 \pm 3.3$ & $58.8 \pm 3.1$ \\
Body fat (\%) & $16.6 \pm 2.6$ & $15.7 \pm 2.0$ & $14.2 \pm 1.7^{\mathrm{ab}}$ \\
Lean body mass (kg) & $48.8 \pm 2.2$ & $49.9 \pm 2.7^{\mathrm{a}}$ & $50.3 \pm 2.5^{\mathrm{a}}$ \\
Fat body mass (kg) & $10.7 \pm 3.3$ & $9.3 \pm 1.5$ & $8.3 \pm 1.3^{\mathrm{a}}$ \\
\hline
\end{tabular}

Values are expressed as mean \pm SD. ${ }^{a} p<.05$ compared to the PP; ${ }^{b} p<.01$ compared to the CP.

Selective loads periodization in the final competitive period maintained maximal oxygen uptake $\left(\mathrm{VO}_{2 \max }\right)$, lower limb muscle power and agility when compared with $\mathrm{PC}(p<.05)$. There was a significant reduction of the maximum isometric strength of the lower limbs and lower back muscles by $11 \%$ $(p<.01)$, as well as reduction abdominal and flexion the arms muscular endurance by $7 \%$ and $18 \%(p<.001)$, respectively, when compared to competitive period. However, when compared to beginning of preparatory period, selective loads periodization maintained maximal oxygen uptake $\left(\mathrm{VO}_{2} \max \right)$, lower limb muscle power, agility, flexibility and muscular endurance of abdominal and flexion the arms in the final competitive period $(p<.05)$.

\section{Leucogram}

Periodization of training did not modify the leucogram (Table 4). In the competitive period the total count of leucocytes, neutophils, lymphocytes, monocytes, eosinophils and basophils did not change when compared with the beginning of period preparatory $(p>.05)$ (Table 4$)$. In the final competitive period, the total count of leucocytes increased $28 \%$ when compared with the beginning of preparatory period $(p<.01)$ (Table 4$)$. This increase was presented by the count of neutrophils in the final competitive period, which was increased by $63 \%$ compared to competitive period $(p<.01)$. The number of lymphocytes, monocytes, eosinophils and basophils did not change in the final competitive period when compared with the beginning of preparatory period and competitive period $(p>.05)$ (Table 4). All changes white blood cells were in the normal range.

\section{Erytrogram}

Selective loads periodization increased by $9 \%$ the mean cell volume in the competitive period when compared with the beginning of preparatory period $(p<.05), \mathrm{A} 0.5 \%$ increase in this same parameter was seen in the final competitive period when compared with the competitive period $(p<.001)$. There was no significant difference for the mean cell volume in the final competitive period when compared with the beginning of preparatory period $(p>.05)$ (Table 5).

Table 3. Effect of selective loads periodization on physiological and neuromotor characteristics of female futsal players in the beginning of the preparatory (PP), competitive (CP) and final competitive period (FCP).

\begin{tabular}{|c|c|c|c|}
\hline & $\mathrm{PP}$ & $\mathrm{CP}$ & FCP \\
\hline $\mathrm{VO}_{2 \max .}\left(\mathrm{ml} \cdot \mathrm{kg}^{-1} \cdot \mathrm{min}^{-1}.\right)$ & $49.8 \pm 3.3$ & $57.0 \pm 1.4^{\mathrm{a}}$ & $56.1 \pm 2.3^{\mathrm{a}}$ \\
\hline MI strength $(\mathrm{kg})$ & $115.6 \pm 16.5$ & $135.0 \pm 17.5^{\mathrm{a}}$ & $116.3 \pm 13.0^{\mathrm{b}}$ \\
\hline Horizontal jump (cm) & $206.6 \pm 19.0$ & $232.1 \pm 14.2^{\mathrm{a}}$ & $224.9 \pm 17.1^{\mathrm{a}}$ \\
\hline Agility (s) & $9.9 \pm 0.3$ & $9.2 \pm 0.2^{\mathrm{a}}$ & $9.4 \pm 0.3^{\mathrm{a}}$ \\
\hline Flexibility (cm) & $36.8 \pm 5.7$ & $39.9 \pm 5.3^{\mathrm{a}}$ & $40.5 \pm 4.9^{\mathrm{a}}$ \\
\hline Sit-up (rep.) & $53.5 \pm 8.0$ & $62.4 \pm 7.7^{\mathrm{a}}$ & $58.2 \pm 7.5^{\mathrm{ab}}$ \\
\hline Push-up (rep.) & $34.3 \pm 5.3$ & $48.0 \pm 8.0^{\mathrm{a}}$ & $39.5 \pm 7.4^{\mathrm{ab}}$ \\
\hline
\end{tabular}

$\mathrm{MI}=$ maximum isometric. rep. $=$ repetitions. Values are expressed as mean $\pm \mathrm{SD} .{ }^{\mathrm{a}} p<.01$ compared with the PP; ${ }^{\mathrm{b}} p<.01$ compared with the CP.

Table 4. Effect of selective loads periodization on leucogram of female futsal players in the beginning of the preparatory (PP), competitive (CP) and final competitive period (FCP).

\begin{tabular}{lcccc}
\hline & Normal range & PP & CP & FCP \\
\hline Total leucocytes $\left(10^{3} / \mu \mathrm{L}\right)$ & $3.8-9.8$ & $5.7 \pm 1.1$ & $5.9 \pm 1.3$ & $7.4 \pm 1.6^{\mathrm{a}}$ \\
Neutrophils $\left(10^{3} / \mu \mathrm{L}\right)$ & $2.5-7.5$ & $3.1 \pm 1.1$ & $2.7 \pm 0.5$ & $4.5 \pm 1.7^{\mathrm{ab}}$ \\
Lymphocytes $\left(10^{3} / \mu \mathrm{L}\right)$ & $1.2-3.3$ & $2.0 \pm 0.3$ & $2.2 \pm 0.7$ & $2.4 \pm 0.5$ \\
Monocytes $\left(10^{3} / \mu \mathrm{L}\right)$ & $0.2-0.7$ & $0.4 \pm 0.1$ & $0.4 \pm 0.0$ & $0.5 \pm 0.1$ \\
Eosinophils $\left(10^{3} / \mu \mathrm{L}\right)$ & $0.0-0.3$ & $0.1 \pm 0.0$ & $0.1 \pm 0.1$ & $0.1 \pm 0.0$ \\
Basophils $\left(10^{3} / \mu \mathrm{L}\right)$ & $0.0-0.1$ & $0.0 \pm 0.0$ & $0.0 \pm 0.0$ & $0.0 \pm 0.0$ \\
\hline
\end{tabular}

Values are expressed as mean $\pm \mathrm{SD} .{ }^{\mathrm{a}} p<.01$ compared with the PP; ${ }^{\mathrm{b}} p<.01$ compared with the CP. 
Table 5. Effect of selective loads periodization on erytrogram of female futsal players in the beginning of the preparatory (PP), competitive (CP) and final competitive period (FCP).

\begin{tabular}{lcccc}
\hline & Normal Range & PP & CP & FCP \\
\hline Erytrocytes $(\mathrm{M} / \mu \mathrm{L})$ & $3.9-5.0$ & $4.4 \pm 0.2$ & $4.4 \pm 0.3$ & $4.4 \pm 0.2$ \\
Hemoglobin $(\mathrm{g} / \mathrm{dL})$ & $12.1-15.1$ & $12.9 \pm 0.8$ & $12.9 \pm 0.9$ & $12.7 \pm 0.8$ \\
Hematocrit $(\%)$ & $36.1-44.3$ & $39.1 \pm 2.6$ & $39.4 \pm 2.8$ & $38.7 \pm 2.5$ \\
MCV (fL) & $80.0-97.6$ & $87.9 \pm 3.0$ & $88.5 \pm 2.7^{\mathrm{a}}$ & $87.4 \pm 2.9^{\mathrm{b}}$ \\
MCH (pg) & $26.7-33.7$ & $29.1 \pm 1.1$ & $29.0 \pm 1.1$ & $28.7 \pm 1.1^{\mathrm{ab}}$ \\
MCHC $(\mathrm{g} / \mathrm{dL})$ & $32.7-35.5$ & $33.1 \pm 0.2$ & $32.9 \pm 0.3$ & $32.8 \pm 0.3^{\mathrm{a}}$ \\
\hline
\end{tabular}

$\mathrm{M}=$ millions. Values are expressed as mean $\pm \mathrm{SD} .{ }^{\mathrm{a}} p<.01$ compared with the $\mathrm{PP} ;{ }^{\mathrm{b}} p<.05$ compared with the CP.

In the final competitive period, the mean corpuscular hemoglobin decreased by $1.3 \%$ and $1.2 \%(p<.05)$ when compared with the beginning of preparatory period and competitive preparatory, respectively. The mean cell hemoglobin concentration decreased by $0.7 \%$ when comparing final competitive period with the preparatory period $(p<.05)$ (Table 5$)$. Erytocytes, hemoglobin and hematocrit did not change $(p>.05)$.

\section{Cortisol}

In the beginning of preparatory period the mean plasma cortisol was $14.0 \pm 2.3 \mathrm{ug} / \mathrm{dL}$ (Figure 1). Selective loads periodization increased the plasma cortisol concentration by $26 \%$ and $28 \%$ in the competitive period and final competitive period, respectively, when compared with the beginning preparatory period (17.6 \pm $3.0 \mathrm{ug} / \mathrm{dL}$ and $18.0 \pm 3.0 \mathrm{ug} / \mathrm{dL}$, respectively, $p<.01$ ) (Figure 1).

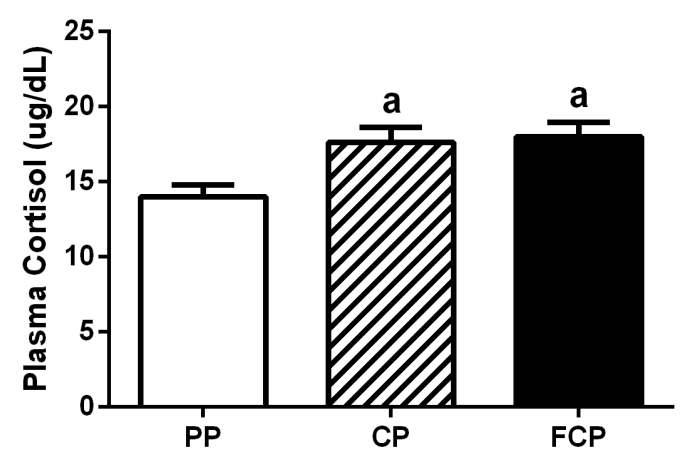

Figure 1. Effect of selective loads periodization on plasma cortisol of female futsal players in the onset of the preparatory (PP), competitive (CP) and final competitive period (FCP). Values are expressed as mean \pm SD. ${ }^{a} p<.01$ compared with the PP.

\section{Plasma $\operatorname{Ig} A$}

In the beginning of preparatory period the concentration of IgA in plasma was $158.2 \pm 29.2 \mathrm{mg} / \mathrm{dL}$ (Figure 2 ). This parameter increased by $8.5 \%$ in the competitive period compared with the beginning preparatory period $(171.6 \pm 29.6 v s .158 .2 \pm$ $29.2 \mathrm{mg} / \mathrm{dL}, p<.01)$. In the final competitive period the mean IgA returned to values similar to the preparatory period (160.6 $\mathrm{mg} / \mathrm{dL} \pm 27.9 \mathrm{mg} / \mathrm{dL}, p>.05)$ (Figure 2).

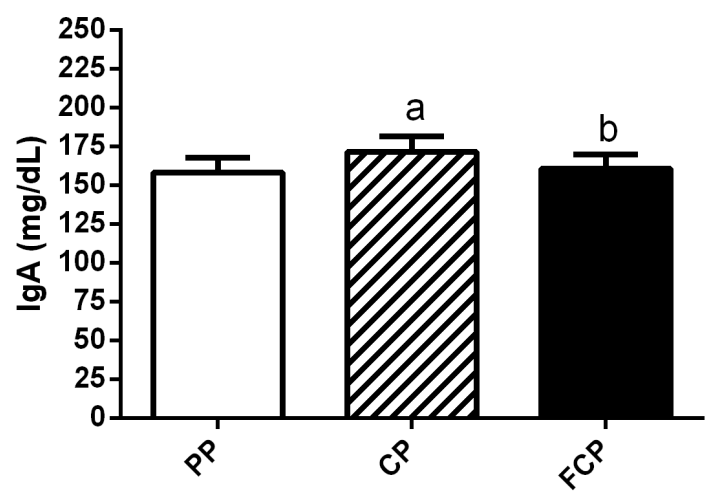

Figure 2. Effect of selective loads periodization on plasma Immunoglobulin A (IgA) of female futsal players in the beginning of the preparatory (PP), competitive (CP) and final competitive period (FCP). Values are expressed as mean $\pm \mathrm{SD} .{ }^{\mathrm{a}} p<.01$ compared with the PP; ${ }^{\mathrm{b}} p$ $<.05$ compared with the CP.

\section{Discussion}

The aim of this study was to evaluate, during competitive season, the effects of selective loads periodization on physical performance and biochemical parameters in a professional female futsal team. Our main finding was that with selective loads periodization the female futsal players increased the performance physical and sustained it until final competition period. Nevertheless, the evaluated changes in the biochemical parameters remained within the normal ranges during competitive season. The model of selective loads have been used in studies with basketball (Moreira, Okano,Souza, Oliveira, \& Gomes, 2005; Moreira, Oliveira, Ronque, Okano, \& Souza, 2008), volleyball (Mazon et al., 2013) and male futsal players (Cetolin \& Foza, 2010; Thiengo et al., 2013). However, according to the best of our knowledge, no study has investigated the effects of this model on female futsal players.

Selective loads periodization increased the lean body mass, decreased body fat (\%) and fat body mass in the CP and FCP compared with the beginning PP (Table 2). Female futsal players move strongly with high energy expenditure and an extremely high metabolic demand in neuromuscular and game (Cyrino, Altimari, Okano, \& Coelho, 2002), therefore, the increase in lean mass and decreased fat mass, allows a better performance. 
Cyrino et al. (2002) highlights that futsal is a modality that involves the execution of rapid movements, jumps and changes direction constantly and any excess body weight in the form of fat may cause damage in the performance of players.

In our research, all physical capacities improved in the $\mathrm{CP}$ with selective loads periodization and the maximal oxygen uptake ( $\left.\mathrm{VO}_{2} \max \right)$, lower body strength, muscle power, agility, flexibility and muscular endurance of abdominal and flexion the arms, when compared with the beginning PP, were maintained in the PCF (Table 3). Each physical capacity plays a decisive role in the performance of athletes. Maximal oxygen uptake $\left(\mathrm{VO}_{2} \mathrm{max}\right)$ will provide faster recovery between intense stimuli, increasing the permanence of the players in game. Agility will be used in high-speed movement and change of direction and the offensive and defensive phases. Muscle power of lower limbs is essential for rapid movements as jumps, kicks, dribbling, disputes for spaces and markings. (Castagna, D'ottavio, Vera, \& Alvarez, 2008; Castagna \& Alvarez, 2010; Witvrouw, Danneels, Asselman, D'have, \& Cambier, 2003; Achour Junior, 1996). Therefore, it is essential to improve the physical capabilities during the preparatory period and maintain the competitive period to withstand all requirements imposed by the games and technical/tactical training. To our knowledge, our study is the first to report the effect of a periodization program in female futsal players during training and competitive season.

In the present research, the white blood cells increased significantly in the FCP compared with PP (Table 4). This leukocytosis occurred mainly due to the significant increase of $63 \%$ neutrophils (Table 4). According to Todo-Bom and Pinto (2007), neutrophils, and in a less extent lymphocytes and monocytes, are responsible for leukocytosis after exercise. This cell count might remain high by 24 hours depending upon intensity and duration of exercise. In our periodization, the $9^{\text {th }}$ mesocycle had aimed to enhance the physical trainings, increasing overload to prepare female futsal players in order to the last competition of the season, which may explain the leukocytosis. Although leukocytosis indicate inflammatory processes that might reduce physical performance, in this research the values remained within the normal range $(3.8$ $-9.810^{3} / \mu \mathrm{L}$ ) and there were no significant reduction in physical performance of female futsal players in the FCP.

Hematologic indices were modified in the CP and FCP compared to beginning PP (Table 5). In the CP, the MCV increased $9 \%$ probably due to a positive adaptation to aerobic training during the preparatory period, improving the transport of oxygen to the muscle cells. Such modification can be involved in the observed $14 \%$ increase in the players' $\mathrm{VO}_{2} \max$ (Table 3). According to Schmidt and Prommer (2008), total hemoglobin is a key determinant for aerobic capacity with strong positive correlations with $\mathrm{VO}_{2 \max }$ in adults. Nevertheless, the $\mathrm{MCH}$ and MHCM decreased in the FCP compared to beginning PP, however, in this research the values remained within the normal range (Table 5). In a study that evaluated the hematologic indices in 27 soccer players during three seasons of training and competitions, the results showed that hemoglobin decreased in the $\mathrm{CP}$ and remained under FCP compared with the beginning of the season (Malcovati, Pascutto, \& Cazzola, 2003), which it did not happened in our study. In other study, Mørkeberg,
Belhage, and Damsgaard (2009) evaluated hematologic indices for 1 year in 28 professional cyclists, the results also showed that hemoglobin and hematocrit were reduced during periods of competition. We infer that the divergence between our results and the previous reported studies may be related to the periodization of training. With the control of overload training (volume, intensity and recovery) during all training process, the negative effects could be decreased.

In our study, the plasma cortisol concentration increased in the $\mathrm{CP}$ and remained elevated in the PCF compared to beginning PP on female futsal players (Figure 1). These data are in agreement with other authors who indicated that cortisol levels are considered as an indicative factor of accumulated stress mainly on the competitive season (Córdova, Sureda, Tur, \& Pons, 2010; Garcia, 2008; Engelmann, Landgraf, \& Wotjak, 2004). Viru (1992) suggested that the adaptation to stress induced by exercise was a mechanism to maintain the level of performance; however, excessive stress leads to imbalance between training stress and recovery resulting in an overtraining situation (Halson \& Jeukendrup, 2004). Kraemer et al. (2004), explains that elevated cortisol concentrations lead to increased binding at the glucocorticoid receptor, resulting in a reduction in muscle protein synthesis and concomitant loss of muscle strength and physical performance. Our results show that the control of overload training (intensity, volume and recovery) carried out with the periodization of training reflected on cortisol level that were within the normal range (Figure 1) and did not modify the physical performance of female futsal players (Table 3).

Immunoglobulin plays an important role in protecting the body against infectious diseases and an increase in immunoglobulin concentration is usually interpreted to represent enhanced immunity (Koch, 2010; Mackinnon, 1996). Depending on the Ig isotype measured, moderate physical activity either stimulates or has no effect on Ig, whereas heavy exercise or periods of intense exercise training are associated to the suppression of Ig levels (Mackinnon, 1996). Others factors such as adrenocorticotropin hormone, cortisol, catecholamines, and other hormones have also important effects on immune response to exercise (Karacabey et al., 2005; Ostrowski, Schjerling, \& Pedersen, 2000; Nieman et al., 1993; Nieman \& Nehlsen-Cannarella, 1991). Interestingly, the plasma Immunoglobulin A (IgA) increased by $8.5 \%$ in the CP compared to beginning PP and even in the most intense periods of training as it happened on the $9^{\text {th }}$ and $10^{\text {th }}$ mesocycle, the IgA not modified compared to the PP (Figure 2 ). In an investigation with professional volleyball players, evaluated on the beginning and final of season (4 months of training and competition), the serum levels of IgA did not modify, corroborating our data (Córdova et al., 2010). In another study carried out by Hejazi \& Hosseini (2012), with 13 endurance runners, volunteers were evaluated on the beginning and after preparation phases and before competition. The researchers did not observe changes in IgA during the competitive season as well. Gleeson et al. (1995), analyzed IgA, IgG and IgM serum during a competitive season of 7 months, in 26 elite swimmers (15 males and 11 females), the immunoglobulins were $10 \%$ below the normal clinical values in the finale competitive season. Therefore, it could be proposed that to keep the levels of serum concentration of $\operatorname{IgA}$ within normal ranges would potentially 
represent a protective factor for futsal players, in order to decrease the risk of injury and infection during the most intense training phases and competitive seasons.

It is important to mention that the female futsal team involved in this study showed some expressive results during the 2011 Brazilian season. The Kinderman team remained among the best three female futsal teams in the country, being placed in second in the National League and State Championship, first in the Brazilian College Games and third in the Open Games of Santa Catarina. Furthermore, because to performance of Kindermann team during 2011 season four athletes were called to compete in both World and South American Championship. Therefore, the selective loads periodization was in some way related (coincidently or not) to important achievements of the team. Such achievements might be a result of the physical performance of the athletes, one of the main objectives of training periodization.

Although the present study provide evidences that the periodization model of selective loads was effective for maintaining physical performance female futsal players during the competitive season, some limitations should be considered. With the lack of a control group we cannot exclude that other models of training periodization would find similar results.

\section{Conclusion}

In summary, our data show that the selective loads periodization model adapted to the female futsal is adequate and attends the requirements of the sport, maintaining the physical performance of the female futsal players throughout the competition and final competitive periods. Another important feature of this study was that biochemical parameters were kept within normal ranges throughout the competition, even during the most intense training phases. Additional studies, focused in female futsal, should address further performance parameters or training periodization models throughout the competitive season in order to increase the scientific data to this field.

\section{References}

Achour Junior, A. (1996). Bases para Exercícios de Alongamento Relacionado com a Saúde e no Desempenho Atlético (Foundations for stretching exercises related to the health and athletic performance). Paraná: Midiograf.

Avloniti, A.A., Douda, H.T., Tokmakidis, S.P., Ortsaris, A.H., Apadopoulou, E.G., \& Spanoudakis, E.G. (2007). Acute effects of soccer training on white blood cell count in elite female players. International Journal of Sports Physiology and Performance, 2, 239-249.

Castagna, C., D'ottavio, S., Vera, J.G., \& Alvarez, J.C. (2008). Match demands of professional futsal: a case study. Journal of Science and Medicine in Sports, 12, 490-494.

Castagna, C., \& Alvarez, J.C. (2010). Physiological demands of an intermittent futsal-oriented high-intensity test. Journal of Strength and Conditioning Research, 24, 1-8.

Cetolin, T., \& Foza, V. (2010). Periodization futsal: description of the use of a method of training loads based on selective. Brazilian Journal of Biomotricity, 4, 24-31.

Córdova, A., Sureda, A., Tur, J.Á., \& Pons, A. (2010). Immune res- ponse to exercise in elite sportsmen during the competitive season. Journal of Physiology and Biochemistry, 66, 1-6.

Cyrino, E.S., Altimari, L.R., Okano, A.H., \& Coelho, C.F. (2002). Efeitos do treinamento de futsal sobre a composição corporal e o desempenho motor de jovens atletas (Futsal training effects on body composition and motor performance of young athletes). Revista Brasileira de Ciência e Movimento, 10, 41-46.

Engelmann, M., Landgraf, R., \& Wotjak, C.T. (2004). The hypothalamic-neurohypophysial system regulates the hypothalamic-pituitary-adrenal axis under stress: an old concept revisited. Frontiers in Neuroendocrinology, 25, 132-149.

FIFA (2006). Futsal and beach soccer enjoying rising interest, FIFA research shows. Retrieved from http: //www.fifa.com/en/media/ index/0,1369,122047,00.html.

Garcia, M.C. (2008). Cortisol sanguíneo e salivar como indicador de estresse (Cortisol sanguíneo e salivar como Carlos de estresse). Tese de Doutorado, Universidade de Campinas, UNICAMP.

Gleeson, M., Mcdonald, W.A., Cripps, A.W., Pyne, D.B., Clancy, R.L., \& Fricker, P.A. (1995). The effect on immunity of long-term intensive training in elite swimmers. Clinical \& Experimental Immunology, 102, 210-216.

Gomes, A.C. (2002). Treinamento desportivo: estruturação e periodização (Sports training: structuring and periodization). Porto Alegre: Artmed.

Gordon, C.C., Chumlea, W.C., \& Roche, A.F. (1988). Stature, recumbent length, and weight. In: T.G. Lohman, A.F. Roche, R. Martorell (Ed.). Anthropometric standardization reference manual (pp. 3-8). Champaign: Human Kinetics Books.

Harrison, G.G., Buskirk, E.R., \& Carter, L.J. (1988). Skinfold thickness and measurement technique. In: T.G. Lohman, A.F. Roche, R. Martorell (Ed.). Anthropometric standardization reference manual (pp. 55-70). Champaign, Illinois: Human Kinetics Books.

Halson, S.L., \& Jeukendrup, A.E. (2004). Does overtraining exist? An analysis of overreaching and overtraining research. Sports Medicine, 34, 967-981.

Hejazi, K., \& Hosseini, S.R.A. (2012). Influence of Selected Exercise on Serum Immunoglobulin, testosterone and Cortisol in Semi-Endurance Elite Runners. Asian Journal of Sports Medicine, 4, 185-192.

Jackson, A.S., \& Pollock, M.L. (1978). Generalized equations for predicting body density of men. British Journal of Nutrition, 40, 497-504.

Johnson, B.L., \& Nelson, J.K. (1979). Practical measurements for evaluation in physical education. Minnesota: Burgess Publishing Company.

Karacabey, K., Saygin, O., Ozmerdivenli, R., Zorba, E., Godekmerdan, A., \& Bulut, V. (2005). The effects of exercise on the immune system and stress hormones in sportswomen. Neuroendocrinology Letters, 26, 361-366.

Koch, A.J. (2010). Immune response to resistance exercise. American Journal of Lifestyle Medicine, 11, 244-252.

Kraemer, W.J., French, D.N., Paxton, N.J., Häkkinen, K., Volek, J.S., Sebastianelli, W.J., ...Knuttgen, H.G. (2004). Changes in exercise performance and hormonal concentrations over a Big Ten soccer season in starters and nonstarters. Journal of Strength and Conditioning Research, 18, 121-128.

Leger, L.A., \& Lambert, J.A. (1982). Maximal multistage 20-m shuttle run test to predict $\mathrm{VO}_{2} \max$. European Journal of Applied Physiology, 49, 1-12.

Matsudo, V.K.R. (1987). Testes em ciências do esporte (Tests in sports science). São Caetano do Sul: CELAFISCS.

Malcovati, L., Pascutto, C., \& Cazzola, M. (2003). Hematologic passport for athletes competing in endurance sports: a feasibility study. Haematologica, 88, 570-581.

Mackinnon, L.T. (1996). Immunoglobulin, antibody, and exercise. Exercise Immunology Review, 2, 1-35. 
Mazon, J., Gastaldi, A., Di Sacco, T., Cozza, I., Dutra, S., \& Souza, H. (2013). Effects of training periodization on cardiac autonomic modulation and endogenous stress markers in volleyball players. Scandinavian Journal of Medicine \& Science in Sports, 23, 114-120.

Moreira, A., Oliveira, P. R., Okano, A.H., Souza, M., \& Arruda, M. (2004). A dinâmica de alterações das medidas de força e o efeito posterior duradouro do treinamento em basquetebolistas submetidos ao treinamento em bloco (The dynamics of changes of the measures of force and the subsequent long-lasting effect training in basketball players submitted to block training). Revista Brasileira de Medicina do Esporte, 10, 243-250.

Moreira, A., Okano, A. H., Souza, M., Oliveira, P. R., \& Gomes, A. C. (2005). Sistema de cargas seletivas no basquetebol durante um mesociclo de preparação: implicações sobre a velocidade e as diferentes manifestações de força (Selective loads system in basketball during a mesociclo of preparation: implications on the speed and the different manifestations of strength). Revista Brasileira de Ciência e Movimento, 13, 7-15.

Moreira, A., Oliveira, P.R., Ronque, E.R.V., Okano, A.H., \& Souza, M. (2008). Análise de diferentes modelos de estruturação da carga de treinamento e competição no desempenho de basquetebolistas no Yo-Yo intermittent endurance test (Analysis of different models of structuring the training load and competition in the performance of basketball players in the yo-yo intermittent endurance test). Revista Brasileira de Ciências do Esporte, 29, 165-183.

Mørkeberg, J.S., Belhage, B., \& Damsgaard, R. (2009). Changes in blood values in elite cyclist. International Journal of Sports Medicine, 30, 130-138.

Nieman, D.C., Miller, A.R., Henson, D.A., Warren, B.J., Gusewitch, G., Johnson, R.L., ...Nehlsen-Cannarella, S.L. (1993). Effects of high- $v s$. moderate intensity exercise on natural killer cell activity. Medicine Science and Sports Exercise, 25, 1126-1134.

Nieman, D.C., \& Nehlsen-Cannarella, S.L. (1991). The effects of acute and chronic exercise on immunoglobulins. Sports Medicine, 11, 183-201.

Ostrowski, K., Schjerling, P., \& Pedersen, B.K. (2000). Physical activity and plasma interleukin-6 in humans - effect of intensity of exercise. European Journal of Applied Physiology, 83, 512-515.

Pollock, M.L., \& Wilmore, J.H. (1993). Exercícios na saúde e na doença: avaliação e prescrição para prevenção e reabilitação (Exercises in health and disease: evaluation and prescription for prevention and rehabilitation). Rio de Janeiro: Medsi.

Salles, J.G.C., \& Moura, H.B. (2013). Indoor Football-Futsal. In Da Costa, L.P. (Org.), Atlas do Esporte no Brasil (pp. 343). Rio de Janeiro: Shape.

Schmidt, W., \& Prommer, N. (2008). Effects of various training modalities on blood volume. Scandinavian Journal of Medicine \& Science in Sports, 18, 57-69.

Siri, W.E. (1961). Body composition from fluid spaces and density. In: J. Brozek, A. Henschel (Ed). Techniques for measuring body composition (pp. 223-244). Washington: National Academy of Science.

Thiengo, C.R., Talamoni, G.A., Silva, R.N.B, Morceli, H.S., Porfírio, J.C., dos-Santos, J.W., \& Drigo, A.J. (2013). Efeito do modelo de periodização com cargas seletivas sobre capacidades motoras durante um mesociclo preparatório em jogadores de futsal (Effect of periodization model with selective loads on motor skills during a preparatory mesociclo in futsal players). Revista Brasileira de Ciências do Esporte, 35, 1035-1050.

Todo-Bom, A., \& Pinto, A.M. (2007). Exercise and immunoinflammatory responses. Revista Portuguesa de Imunoalergologia, 15, 123-133.

Toledo, N., \& Corradine, T. V. (2008). O modelo das cargas concentradas de força no futsal (The model of concentrated loads of strength in futsal). In: P.R. Oliveira (Ed.). Periodização contemporânea do treinamento desportivo: modelo das cargas concentradas de força: sua aplicação nos jogos desportivos (basquetebol, futebol de campo, futsal, voleibol) e luta (Contemporary sport training periodization: model of concentrated loads of strength: its application in sports games (basketball, soccer, futsal, volleyball) and fight) (pp. 117-157). São Paulo: Phorte.

Verchoshansky, Y.V. (1985). Programming and organization of training process [in Russian].Moscow: FiS Publisher.

Wahl, P., Güldner, M., \& Mester, J. (2014). Effects and Sustainability of a 13-Day High-Intensity Shock Microcycle in Soccer. Journal of Sports Science and Medicine, 13, 259-265.

Wells, K.F., \& Dillon, E.K. (1952). The sit and reach - a Test of back and leg flexibility. Research Quarterly for Exercise and Sport, 23,115-118.

Witvrouw, E., Danneels, L., Asselman, P., D’have, T., \& Cambier, D. (2003). Muscle flexibility as a risk factor for developing muscle injuries in male professional soccer players. A prospective study. American Journal of Sports Medicine, 31, 41-46.

\section{Authors' note}

Ricelli E. R. da Rocha is affiliated with the Italian University Institute of Rosario, Rosario (Instituto Universitário Italiano de Rosario), Argentina; Universidade do Alto Vale do Rio do Peixe, Caçador, West University of Santa Catarina (Universidade do Oeste de Santa Catarina), Brazil.

Everson A. Nunes is affiliated with the Physiological Sciences Department, Biological Sciences Center, Federal University of Santa Catarina (Universidade Federal de Santa Catarina), Brazil.

Graciela D. Venera is affiliated with the Italian University Institute of Rosario, Rosario (Instituto Universitário Italiano de Rosario), Argentina; Institute of Chemical and Physicochemical, Conicet, Buenos Aires, Argentina.

\section{Acknowledgments}

The authors would like to thank the Kindermann team (Brazil) for their participation in the study. We would also like to thank the clinical analysis laboratory Madalozo Camatti Ltda for the biochemical assessment.

\section{Corresponding author}

Ricelli E. R. da Rocha

Rua Victor Baptista Adami, 77, ap.305, Caçador, SC, Brazil.

Email: ricelliendrigo@yahoo.com.br

Manuscript received on May 19, 2014

Manuscript accepted on February 5, 2015

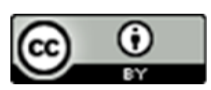

Motriz. The Journal of Physical Education. UNESP. Rio Claro, SP, Brazil - eISSN: 1980-6574 - under a license Creative Commons - Version 3.0 